\title{
Productive restructuring and labour
}

\author{
the auto industry in Brazil
}

\author{
Marcia Leite \\ Marcia Leite is Professor of Labour Studies at the University of \\ Campinas in Brazil.
}

\begin{abstract}
In the early 1980 's, Brazilian industry underwent a crisis of the previous accumulation model, ushering in a period in which the country lost international competitiveness. This paper traces the changes that have taken place since then, including the further changes that have taken place since 2003. It concludes that the last four years have not differed much from the earlier pattern, even though several new industrial policies have been introduced with the aim of spurring technological innovation. The paper investigates the reasons for this, seeking to underline the limits and the potentialities of such policies, given the general global context. In order to do so, it analyses managerial strategies and innovative processes in the Brazilian manufacturing sector as a whole, with a special focus on the automotive sector, and discusses the implications of this restructuring for labour.
\end{abstract}

\section{Introduction}

In the 25 year period between 1955 and 1980, Brazilian manufacturing grew at high rates, rising from $21.2 \%$ of GDP in 1955 to $33.1 \%$ in 1981 . At the same time Brazil went through a rapid process of technological innovation, under an import substitution development model. However the early 1980s were marked by a crisis of this accumulation model, and the beginning of a period in which the country lost international competitiveness, parting its way from the other countries with similar levels of economic development, which were becoming more competitive worldwide. Recent years have not seen a strong growth in either GDP or competitiveness, although a modest set of industrial policies has been put forward in order to spur technological innovation.

This text discusses these issues, seeking to underline the limits and the potentialities of such policies, as well as the difficulties and contradictions inherent in the Brazilian restructuring process. It does this first by analysing innovation processes in the manufacturing industry in general and then focussing specifically on the automotive sector, looking at the implications of this restructuring on labour.

In general, these strategies have not lived up to the original expectations of the economic actors who framed them; neither have they made possible higher growth rates to take advantage of the extremely favourable conditions of the international 
economy. However the regulatory context for labour has changed considerably, since governmentofficials have insisted on greater labour flexibility. In this sense, even if the current industrial polices do result in more competitive firms and better labour and salary conditions for the manufacturing sector, the maintenance of current macroeconomic policies and attempts to make work relations even more flexible might nevertheless lead to a significant deterioration in overall labour conditions.

\section{The historical context}

There already exists a social science literature consensus on the limits of the productive restructuring process in Brazil, especially when compared to the experience in the more industrialised countries.

The first papers discussing these limits date back to the late 1970s, a time when the practice of setting up Quality Control Circles began to spread among Brazilian companies, albeit without the implementation of significant changes in the forms of labour organisation or significant investment in new equipment. The partial and reactive character of the strategy was quickly detected by scholars who drew attention to the narrow range of issues dealt with in these circles (Salermo, 1985), to the fact that the circles only included skilled workers, bosses and supervisors (Hirata, 1983), as well as corporate attempts to divert workforce organisation efforts in the workplace to alternative forms of labour organisation under greater managerial control (Leite, 1994). Faced with these limitations, the failure of the strategy became evident by the middle of the following decade, when many of the programmes were wound up and the companies began to focus their attention on other innovative techniques.

The second phase of the workplace innovation process can be traced back to the moment when Brazil was coming out of the recession of the early 1980s and continued until the early 1990s. It was marked by the rapid diffusion of new technologies, as well as the partial adoption of various Japanese techniques such as 'just in time', statistical process control, production cells, and the kanban ${ }^{1}$ system. Again many researchers emphasised the limits of this process, mainly evident in employers' resistance to allowing workers' participation in decision-making (Hirata et al, 1992; Leite \& Silva, 1991) and the inability of the labour administration policies practiced at the time to accommodate the principles of workers' involvement and labour flexibility required for these Japanese techniques to be effective (Leite, 2003).

In the early 1990s a third phase was entered, when firms began to opt for a more systemic modernisation strategy, investing heavily in organisational changes based on Japanese techniques as well as in new labour administration methods, which were more compatible with principles of flexibility and with workers' involvement in quality and productivity. This process was not just a reaction to Brazil's deepening economic crisis in the early 1990s (which caused a dramatic drop in domestic demand, forcing firms to seek new markets abroad), but also a consequence of the open market policies adopted by the government, which increased competition between firms, under international production practices. This created a strong incentive for companies to invest in the modernisation of production methods.

1

A signalling system linked to 'just in time’ production systems used for inventory maintenance. 
The production and labour innovations already started in the previous period spread very quickly in this phase but during this period there was also a rapid restructuring of industrial organisation as a whole, Organisational structures were transformed to make them more horizontal, whilst there was focus on core products, with outsourcing of any activities which were seen as non-core.

In this stage of the technological modernisation process there was a major emphasis on changing the forms of labour administration, with the aim of achieving greater workforce stability, developing training policies, and simplifying not only the multiple occupational and wage structures but also the hierarchical structures (Gitahy \& Rabelo, 1991; Humphrey, 1991; Castro, 1994; Leite, 1994), discarding previous patterns of labour utilisation.

A fourth phase commenced in the mid 1990s, when inflation control and currency stabilisation (achieved through the Real Plan, launched in 1994) gave firms some respite from crisis management and the possibility of resuming long term projects. In this context, the restructuring process gained a new momentum, especially in the more competitive sectors.

Between 1995 and 1999, registered employment in the manufacturing sector felt by $13 \%$. This was associated with restructuring processes based on the reduction in the numbers of industrial workers. As De Negri et al (2006) point out, 'A substantial proportion of modernisation investments made by firms during

the 1990s were directed to the purchase of labour-saving machinery and equipment, reducing particularly low skilled job positions'

These changes did not extend right across the Brazilian economy, as studies undertaken during the second half of the decade show. Nonetheless this new phase has been marked by an important trend - the focus on core products - which has brought Brazilian companies increasingly into line with global tendencies, in adopting new forms of industrial organisation, with the emergence of production chains based on new relations between companies. In fact the latest studies have highlighted a strong process of firm decentralisation, which has affected not only service industries (restaurants, security, cleaning), but also those involved in production.

This trend involves an attempt to concentrate the efforts of each company on the production of those products in which it has an evident competitive advantage, externalising the production of the other components necessary for the manufacture of the final product, configuring a chain structure and implementing an external 'just in time' model into the relations between firms. The identification of this tendency gave birth to an important methodological reorientation in research, which began to replace studies of isolated cases, generally carried out in the leading companies of various sectors, with studies in production chains within the group.

The literature emphasises the systemic character of this process, especially in some sectors which are at the leading edge of technological change, such as the automotive industry. Chain studies, however, have made it clear that there are assymetries in the productive environments which make them up, whether in relation to the different parts of the job which are processed in different links in the productive chain, the technological content of the produced items, the technological and organisational 
innovation, especially the innovation in personnel administration, or the actual content of jobs. Here, it is important to emphasise that the new production concepts are strongly differentiated among the various companies in the chain. It may well be the case that in firms near the top of the chain, where the most sophisticated parts of the productive process are to be found, labour organisation is based on occupational polyvalence, teamworking and highly qualified work. However this is not the case in the companies which form the lowest links in the chain, where the lack of complexity in the work content makes them more likely to create jobs which are poorly paid, unqualified, repetitive, and monotonous, often organised in assembly lines (Leite, 2003).

A number of recent studies have found a marked deterioration in working conditions as one moves downwards along the production chain, where repetitive and disqualified work is the norm, the pace of work increases, control is intensified, fringe benefits are lost, wage levels decrease, job precariousness is the rule, and there is a rise in work-related illnesses (Martins \& Ramalho, 1994; Ruas \& Antunes, 1997; Bresciani, 1997; Carleial, 1997; Leite \& Rizek, 1998; Salerno, 1998; Hirata, 1998a; Nabuco, Neves \& Carvalho, 2002; Leite, 2003). In social terms, perhaps one of the worst consequences these studies have revealed is that with a generalised tendency to subcontracting, the workload diminishes at the virtuous end of the chain at the same time that it expands at the precarious end of the chain (Leite, 2003). These processes overlap with a sexual division of labour. Numerous studies have underlined these links, pointing out that women are generally confined to the more degrading positions, situated at the lower end of the chain (Leite \& Rizek, 1998; Hirata, 1998a), as well as in the more precarious job situations (Bruschini, 1997; Segnini, 1998; Abramo, 1997; Posthuma \& Lombardi, 1997; Hirata, 1998b; Bruschini \& Lombardi, 2003).

\section{The automotive sector: on the edge of the innovation process}

In this transformation process, the automotive sector is the one which has been most innovative in recent years. In fact, the sector has become significantly more global since the 1990s; while production and sales stagnated in the most industrialised countries (North America, Europe and Japan) there was an increase in investment in the less industrialised ones (Nabuco \& Mendonça, 2002:47), among which Brazil clearly stands out, having received a large amount of capital and technology (See Table 1).

Investment in the sector was especially significant between 1997 and 1998, when it reached more than two billion dollars annually. In the late 1990s, Brazil became one of the largest receivers of foreign direct investment in the automotive sector. These investments are related to three factors: first, to the growth in the internal market due to the economic stability of the Real Plan, which also made possible the enlargement of the market for automobiles, mainly ones with low cylinder arrangement; second, to the implementation of the new automotive regulation regime, in 1995, which created a series of incentives for the establishment of new manufacting plants outside the São Paulo-Minas Gerais hub; and third, membership of Mercosur, the Latin American common market, and with it the development of an important regional market (Carleial, Gomes Filha \& Neves, 2002:188). 
Table 1: Car manufacturers in the main emerging economies in the 1990s

\begin{tabular}{|ll|}
\hline China & GM, VW, Peugeot and Daimler Chrysler \\
\hline Indonesia & Toyota, Honda, Mazda, Mitsubishi and Suzuki \\
\hline Malaysia & Toyota and Mitsubishi \\
\hline Thailand & Toyota, Nissan, Honda, Mazda and Mitsubishi \\
\hline Korea & Mitsubishi, GM and Ford \\
\hline Taiwan & Nissan and Ford \\
\hline India & Honda, Mitsubishi, GM, Ford and Peugeot \\
\hline Mexico & Nissan, GM, Ford, VW and Daimler Chrysler \\
\hline Brazil & $\begin{array}{l}\text { Toyota, Nissan, Honda, GM, Ford, VW, Fiat, Renault, Peugeot, Daimler } \\
\text { Chrysler and Mitsubishi }\end{array}$ \\
\hline Venezuela & Ford, VW and Fiat \\
\hline Argentina & Toyota, GM, Ford, VW, Fiat, Renault, Peugeot and Daimler Chrysler \\
\hline
\end{tabular}

Source: Anfavea (2000); Prepared by: Nabuco et al (2002)

As Carleial, Gomes Filha \& Neves (2002:188) explain, the new automotive regulation regime triggered a fierce struggle to attract firms through guaranteed benefits by means of protocols signed by the states and the manufacturers. These agreements showed an aggressive state policy that involved trading land rights and infrastructure works for job creation compromises.

One of the most important aspects of this restructuring process was the decentralisation of the sector. Whereas the industry had been strongly concentrated until 1975 in São Paulo region, from the 1990s on, all the new factories were sited in other regions of the country, spreading along a corridor which extends from the state of Bahia all the way down to the state of Rio Grande do Sul.

Table 2: New investment in the automotive sector in Brazil, 1997/1999

\begin{tabular}{|c|c|c|c|}
\hline New Plants & State & $\begin{array}{r}\text { Investments (US\$ mil- } \\
\text { lions) }\end{array}$ & Jobs \\
\hline Ford & Bahia & 1300 & 2500 \\
\hline Renault & Paraná & 1000 & 2000 \\
\hline Mercedes Benz & Minas Gerais & 820 & 1500 \\
\hline Audi - VW & Paraná & 700 & 1500 \\
\hline GM & $\begin{array}{l}\text { Rio Grande do } \\
\text { Sul }\end{array}$ & 700 & 1300 \\
\hline Peugeot/Citroen & Rio de Janeiro & 600 & 2500 \\
\hline Chrysler & Paraná & 315 & 400 \\
\hline Fiat-Iveco & Minas Gerias & 240 & 2000 \\
\hline Toyota & São Paulo & 150 & 350 \\
\hline Honda & São Paulo & 150 & 400 \\
\hline Total & & 5975 & 14450 \\
\hline
\end{tabular}

Source: Nabuco et al (2002) 
Although some studies argue that fiscal incentives were the main motive (Arbix \& Rodriguez-Posi, 1999), this decentralisation can be related to several other factors too. Among the most important of these were cheap labour, good access to raw materials, and low levels of union organisation (Nabuco \& Mendonça, 2002:55).

The new factories were designed along principles embodying modern strategies of competitiveness based on:

'Production of world cars, use of world technologies, local markets, local production with global references, industrial parks, modular association, production deverticalisation, technological and productive partnerships along the chain, simultaneous product and process development, utilisation of systems and integrated logistic quality tools' (Zawislak \& Melo, 2002:107-8).

Another study concluded that:

'This organisational format can very well adapt itself to the lean production system where production is solely in response to demand, where each car being assembled has already been ordered by some dealer. Direct labour organisation suffers the consequences of these changes and replaces, as a trend, the individualised work governed by the relationship between individual workers and their own workstations, for team work, dominated by relationships between group members. (Carleial, Gomes Filha \& Neves, 2002:208)

Modular association is an important aspect of the restructuring process. Abreu et al (2000) define this as a system in which 'the component suppliers finance a part of the factory and organise the assembly of their components on site'. Inititated in the new Volkswagen plant installed in Resende, in 1996, which brought the suppliers into the factory, the model has since spread elsewhere. Initially it was thought of as 'an emerging Brazilian system'of production' (Abreu et al, 2000) with more general implications for the automobile sector.

At the Mercedes Benz plant in Juiz de Fora, for instance, ten suppliers have been brought on site, in charge of 172 vehicle parts. At the Audi-VW plant in Paraná there are thirteen world suppliers located within the industrial complex and at the Renault plant (also in Paraná), which has brought in a total of eighteen world suppliers, there are currently four world suppliers based inside the industrial park (Nabuco \& Mendonça, 2002:77).

One aspect of the production changes that were introduced along with the integrated company deserves special mention. This is the

.... emphasis on time reduction in manufacturing, process rationalisation and replacement of the traditional functional organisation by group technology. Increased automation and the intensification of microelectronic based tools are also relevant. These changes in production administration include techniques and programs generally linked with the Japanese model, such as: the 'iust in time' system, the adoption of kanban and total quality concepts' (Carleial, Gomes Filha \& Neves, 2002:178).

An important feature of the change in the organisation of labour is 
'The relative abandonment of task-specific and job-specific notions for the operation of automated systems and the formation of functional groups requiring multi-skilling, that is, in this context, the employees must be capable of operating, inspecting the quality of activities and performing machines and equipment maintenance. These characteristics confer on the workers greater responsibility in terms of work management and quality (previously a management responsibility). Workers are now required to deal with and prevent malfunctions, unexpected events or incidents. This means that communication takes on a special importance in labour relations' (Carleial, Gomes Filha \& Neves, 2002:179).

It can be concluded that the companies established in the late 1990s came with innovative production and labour administrative techniques based on four key features: first, 'horizontalisation' - a decrease in the number of hierarchical levels; second, decentralisation of structures and decisions with more and more employee involvement in decision-making, participation and responsibility for the organisation and results of their own work, although this participation is limited to their functions and tasks in the workgroup in which they are placed; third, integration and participation in team work; and fourth, an integral production process, which requires from the workers the knowledge of the full automobile production process (Pimenta \& Corrêa, 2002:223-4). Although these forms of labour organisation presuppose team work and multi-tasking, studies carried out in the new plants reveal that conflicts linked to the previous forms of organisation still remain, at the same time that new conflicts emerge. The implications for the labour force of this restructuring will be analysed in the next section.

These innovations have helped the sector to achieve a good performance in recent years, as shown by growth in outputs, as well as in exports. By 2004 the automotive vehicles production sector was the sector with highest growth rate in the whole economy, at $29.9 \%$, compared with an average of $8.5 \%$ for Brazil's manufacturing industry as a whole (DIEESE, 2005). At the same time, exports more than doubled between 2002 and 2005 from 424,415 units to 897,079 (ANFAVEA, 2006).

However, despite this export growth, it must not be forgotten that the innovation process in the sector was (and still is) centred in the units catering for the local market, especially with the creation of fiscal incentives to produce the so-called 'popular cars', which have played a pivotal role in boosting internal sales in recent years' (Carvalho, 2005:126).

According to Consoni (2004), the recent restructuring of the manufacturing process has focussed on the nationalisation of products and processes with local suppliers, and in an attempt in advance a process of 'tropicalisation'. This involves adapting the automobile to local market conditions and has several components including: promoting the reinforcement of car suspension to cope with poor road conditions in Brazil; adjusting to local fuels (alcohol and gasoline mixed with alcohol); use of stronger, corrosion-resistant materials; adjusting vehicle specifications to local regulations; and adjusting to the peculiarities of local climate and temperature (Consoni, 2004: 1 and 2).

This author's research has also found some evidence that the manufacturers are developing more sophisticated activities in Brazil which involve deeper knowledge and technological development. Some companies have advanced some way in this process, 
accumulating a capability which allows them 'to incorporate within their Brazilian branches important parts of the vehicle development process, based on a formalised and systematic firm effort'. These companies have generated technologies in Brazil which have acquired a global importance, and have become world centres of excellence, especially in suspension reinforcement, ethanol fuel and low cylinder engine (up to 2.0cc) (Consoni, 2004: 2).

This type of technological innovation is, however, restricted to the companies that were established there during the first phase of implementation of the sector in Brazil, especially Volkswagen and General Motors. The consolidation of this process will require, as Consoni warns (2004: 4), a recovery in GDP growth which is sufficient to increase local production and make full use of these firms' idle capacity.

\section{New automotive sector strategies and their implications for labour}

One of the most important issues which has been raised by the establishment of the new factories relates to job creation. Despite substantial financial incentives to the companies to create jobs, in most cases this has not actually been achieved. Although there has been a higher rate of jobs creation in the sector than in the transformation industry as a whole, the number of direct and indirect jobs created with the new factories, contrary to expectations, has been quite small, disappointing the local government and the local population where the factories were established. When comparing the number of jobs generated to the capital and technological investment, the resulting data are very puzzling. At Chrysler in Paraná, for instance, US\$315 million was invested, creating 400 jobs, establishing an investment/job ratio of US\$787,000. The second largest investment per job is that of Mercedes Benz in Juiz de Fora, at US\$546,000 (Nabuco \& Mendonça, 2002: 58). Although this ratio is somewhat lower in other states where new plants have located, it is very high in almost all cases, implying an extremely high investment level per job created. A case in point is that of DaimlerChrysler, which decided to close its branch in Campo Largo, built in July 1998 for Dakota pick-up truck assembly. Because the production line was idle, the manufacturer initially gave the 250 employees two months paid leave. In 1998, this manufacturer had predicted that the factory would produce12,000 pick-up trucks a year. However, in 2000, it produced only 4,600 vehicles, when its full productive capacity was 40,000 vehicles a year. When Chrysler decided to shut down this branch altogether because of its accumulated losses, its employees were laid off and damaging effects spread to suppliers and around the systemic company network.

Chrysler's decision clearly demonstrates the impossibility of state interference in the decision sphere of multinational automobile companies which have their manufacturing centres outside the country. In fact the protocols signed between car makers and state officials are not binding (Carleial, Gomes Filha \& Neves, 2002:192).

There has also been widespread dissatisfaction with wage levels, as studies have revealed in the case of GM in Juiz de Fora and of Volkswagen and Peugeot-Citroen in Rio de Janeiro. This was expressed, in the case of Volkswagen, through the workers' movements initiated in 1996 and the significant strengthening of the union ${ }^{2}$. In the case

2 With reference to the strengthening of the unions at the new factories installed in Rio de Janeiro, see Ramalho \& Santana (2002). 
of GM, the wages in the São Caetano do Sul factory are about twice as high as those in the Juiz de Fora factory ${ }^{3}$.

Other workers' complaints are related to the intense pace of work, the exhausting and repetitive work content and the high number of workers suffering from RSI (Repetitive Strain Injury). Furthermore, workers within the groups lack autonomy and decision making capabilities and complain about the individualised salaries they receive (despite working in teams) the competition between groups instigated by the management; the lack of promotion prospects inside the company; and the emergence of temporary work.

\section{Technological innovation in the rest of the manufacturing sector}

In spite of strong investments in innovation in the automotive sector and the remarkable restructuring process which the sector has undergone, nothing similar has happened elsewhere in the Brazilian economy.

On the contrary, data for the last few years indicate that, on average, Brazilian firms have done very little when it comes to restructuring themselves. Investments in R\&D are still low, Brazil's export mix is concentrated in primary commodities (which represent $40 \%$ of total exports compared with the world average of $13 \%$ ) and innovation processes are still restricted to the machinery, chemical and electronic sectors which, in 2000 , concentrated $61.6 \%$ of the companies which innovate and carry out product differentiation in the Brazilian industry (Negri, Salerno \& Castro, 2005:26).

The innovation rate 4 is very low (31\%) when compared to European Union countries. Furthermore, survey results show that the majority of Brazilian companies only carried out process innovation, whereas European companies engage in both process and product innovation.

'Innovation only in process and particularly in a process that is new for the firm

(that is, already known on the market), as is predominant in the innovative companies in Brazil, indicates an innovation pattern geared towards cost reduction, strongly associated with the diffusion of technologies already in existence on the market' (Negri, Salerno \& Castro, 2005:31-2).

Another important recent research finding is that, contrary to expectation, the subsidiaries of multinational firms in the country invest even less in technological innovation than national companies; and thus contribute very little to the country's productive restructuring process.

In summary, several studies have concluded that

'There is a reasonable consensus that Brazilian companies' innovative effort is still insufficient or below the expected for an economy which intends to reach higher development rates and to place itself in a more prominent position on the international market' (Negri, Salerno \& Castro, 2005:41).

$3 \quad$ Although in 2005 labour achieved the best wage negotiation results in the last ten years this has not had an impact on these differentials. Wages in the greenfield sites remain typically around half those in the traditional brownfield factories.

$4 \quad$ The innovation rate takes into consideration the percentage of companies with 10 or more workers who engage in any type of innovation (product, process; for the market, for the firm). 
In the meanwhile, the Lula government has been making a significant effort to create industrial policies (non-existant since the mid 1990s) to change current restructuring processes in companies. Here, eight policies, in particular stand out.

The first of these is the Innovation Law, which regulates and facilitates the relationship between science and technology public institutions (universities, institutes and research centres) and private firms, with the aim of encouraging partnership incentives and innovation in the firms.

Second, the government has developed Guidelines for Industrial, Technological Politics and for International Commerce (PITCE) with a strong emphasis on innovation, released in November of $2003^{5}$.

A third initiative was the creation of the Brazilian Agency for Industrial Development (ABDI), geared toward the coordination of PITCE-related activities and public policies.

A fourth initiative was the creation of new programmes at the BNDES (National Bank for Economic and Social Development) to create incentives for industrial development in suitable regions.

The fifth initiative was the coordination of MCT (Trade and Technology Ministry) and FINEP (Fund for Studies and Projects) to encourage joint projects between private firms and science and technology institutions.

A reduction of the IPI (Tax on Manufactured Goods) for capital goods is the sixth initiative in the list.

To this can be added a seventh, the strengthening of the Competitive Forums created in the last year of the previous government, aiming to raise the industrial competitiveness of Brazil's main productive chains on the world market, with measures designed to encourage job creation and improvements in labour and income conditions. It also aimed: to develop production and the regional decentralisation of production activities; to increase exportsn; to promote competitive import substitution; and to strengthen technological training at firm level. Between May and December 2002, eight Competitive Forums were established, dealing with production chains in civil construction, textiles and apparel; plastics; the electronics industrial complex; wood and furniture; leather and shoes, air transportation ${ }^{6}$, and tourism. The Lula government has been trying to strengthen these forums to encompass other sectors, including the aerospace, the primary metal industry, pharmaceuticals, the automotive sector, capital goods, personal hygiene, perfumery and cosmetics. the agro-chemical industry and precious stones and jewellery. The programme consists of actions which aim to act upon the competitive capacity of the Brazilian productive sector through the interaction among business

$5 \quad$ Initially praised both by economists and industrialists upon its release, today these guidelines are regarded with cynicism because they have not been implemented. According to José Ricardo Roriz Coelho of the Competitiveness and Technology Department of FIESP (Sao Paulo State Industrial Federation), the PITCE lack monitoring, follow-up and accountability procedures (Folha de São Paulo, book B, page 6, 25 $5^{\text {th }}$ of May of 2006). $6 \quad$ Civil and military aircraft manufacturing, which is centered on Embraer, is another important example of the industrial modernisation in the country. This firm currently holds the fourth place among the most important aircraft makers in the world arena. See Goldstein (2002). An account of its restructuring process can be found in Neto \& Kassicieh (2004) 
owners, workers, government and the National Congress in a debate seeking the solution for problems in each production chain as well as the formulation of actions and goals, thus creating a development policy across the manufacturing sector.

Finally, the government has created Local Productive Arrangements (APLs), which offer promotion and support for clusters formed by small and mediumsized firms involved in the same economic activity and which make use of qualified labour without a strict hierarchy in labour relations. The essence of APL lies in confidence: self-confidence, mutual confidence and confidence in the public institutions by the entrepreneurs. The APLs are supported by all the Federal Government Ministries in the PPA - Pluri Annual Planning (2004-2007). A permanent inter-ministerial work group (GTP-APL) has been created in order to improve the coordination of the various ministries and non-governmental agencies involved in the promotion of APLs. Activities were initially focussed on eleven pilot APLs distributed throughout the five regions of the country with the purpose of testing the integrated action methodology. A survey updating the country's APLs, carried out in 2005, identified 955 arrangements. This charting exercise and the data arising from it form parts of the information system for APLs and come from 37 governmental and non-governmental institutions, both at the federal and state level, which work with this issue.

Despite these many initiatives, the results of all these policies for the industrial sector are not very satisfactory. Although the available information is limited in quantity, it all leads to the conclusion that a macroeconomic policy based on high interest rates and floating exchange rates has prevented these policies from producing the expected results, even though the manufacturing sector growth rate cannot be considered all that bad. Actually, after a disappointing growth rate of $0.1 \%$ in 2003 , the sector showed a significant rate of $8.5 \%$ in 2004 , which went down, however, to $3.1 \%$ in 2005 . This performance is reflected in the levels of foreign trade, with a $22.6 \%$ export growth rate in 2005 , against a growth in imports of $17 \%$, leaving a trade balance of 44 billion dollars, corresponding to a $33 \%$ growth in relation to 2004. Export growth was higher than the average for global growth in foreign trade. Whereas in Brazil the growth was $22.6 \%$, the global rate was $13.8 \%$. In this way, Brazilian participation in world exports went up from $1.06 \%$ in 2004 to $1.13 \%$ in 2005 (DIEESE, 2005).

\section{Industrial Restructuring and labour}

De Negri et al (2006, chapter 1) present unequivocal evidence of both productivity gains and technological change between 1996 and 2003. For instance, the increase in employment created by a $1 \%$ increase in manufacturing sales was $0.28 \%$ in 1996, but decreased to $0.18 \%$ in 2003 . This process has not been restricted to manufacturing. In the agro industrial complex, the results are even more radical: in 1996 a $1 \%$ increase in sales would imply a $0.23 \%$ increase in total employment but by 2003 , this percentage had reduced to $0.10 \%$ (De Negri et al, 2006, chapter 5). 
From 1999 on, almost $87 \%$ of new jobs were waged jobs. Two thirds of these being registered ones. Part of the explanation for these results, lies in the fact that manufacturing began to grow again in 1999. Up to 2004, 3.4 million jobs were created in manufacturing. Such a deep change in the sectoral economic performance is directly associated with the decision to abandon fixed exchange rates and the strong growth of international trade (Pochmann, Salas \& Leite, 2007).

The manufacturing sector growth that took place in 2004-2005 has had some interesting repercussions on the job market. 1,523,000 new jobs were recorded in 2004 and 1,254,000 in 2005. According to $\operatorname{DIEESE}^{7} 2005$ also saw the best wage negotiations, from labour's point of view, in a decade, with increases above the rate of inflation in $72 \%$ of the agreements. Here, the most positive results were achieved in the manufacturing sector. According to the Director of DIEESE:

'this is the best wage negotiation result obtained since the start of our research, in 1996. Low inflation and interest rate reduction, along with GDP growth, almost continuously over nine quarters, which hadn't happened in the country for 15 years, had a significant impact on the negotiations' (Folha de São Paulo, 2006:B1).

These results raise a final question which needs to be analysed relating to labour rights and flexibility in Brazil. Although some steps in this direction were taken by the previous government, under the current government, regulation in this area has remained practically intact.

The previous government's changes focussed on two main features. First, flexibility in labour contracts was achieved through an increase in the use of fixed-term contracts and the extension of this kind of contract to all economic sectors, with the scope increased to a minimum of six months and a maximum of two years. Second, flexibility in daily working hours was introduced through the implementation of annualised working hours agreements. These involved the creation of a 'bank' of hours which could be spread flexibly over the year, with the aim of reducing overtime payments. This scheme was also linked to initiatives making it easer to employ part-time staff and to release workers to take part in government-funded training programmes. With the exception of the part-time contract, this legislation linked the establishment of the new contracts and the bank of hours with agreements made through collective negotiations between companies and unions.

The current government's labour and union reforms were included in the political agenda of 2004 and have been discussed, according to Araújo, in a forum where State representatives, entrepreneurial associations and trade unions participated (Araújo, 2005:09). This measure has slowed down the flexibilisation process. In Araújo’s opinion, linking the new forms of contract to the agreement with the unions, has 'reduced the bosses' freedom to act in these cases, and has given the unions a certain margin for bargaining.

In this context, the labour precariousness which followed the flexibilisation of rights in many other countries did not take place in Brazil, although this possibility is not to be discounted in the future.

7 DIEESE, the Social and Economic Studies and Research Department, is a research centre funded by the three most important Union Coalitions in Brazil. 


\section{Conclusion}

Several industrial sectors in Brazil have undergone major restructuring and a comprehensive set of industrial policies was created or implemented in 2003. These developments are not trivial. However, although there has clearly been some impact both on exports and on the job market, the results of these initiatives have been much less than expected, either by the business community or the trade unions, especially in the light of the major opportunities for growth the country has experienced in recent years because of the extremely favorable conditions in the international economy. It appears that, without a macroeconomic policy designed to foster growth, the industrial policies have had little space to express themselves. On the other hand, government policy to intensify workforce flexibility does appear to have had some impact.

What are the implications for labour? If in the future industrial policies result in greater competitiveness of Brazilian companies then this could lead to improvements in working conditions and wages. However the maintenance of macroeconomic policies and increases in flexibility in labour relations might lead to a significant deterioration in working conditions.

(C) Marcia Leite, 2007

\section{REFERENCES}

Abreu, A., H. Beynon \& J. Ricardo Ramalho (2000) 'The Dream Factory': VW's Modular Production System in Resende, Brazil', Work Employment and Society; vol 14, no 2: 265-282 Abramo, L. (1997) 'Imagens de Gênero e Políticas de Recursos Humanos na Modernização Produtiva', São Paulo em Perspectiva, vol. 11, São Paulo: Revista da Fundação Seade

ANFAVEA (2006) Anuário da Indústria Automobilística Brasileira, São Paulo: Associação Nacional dos Fabricantes de Veículos Automotores

Araújo, Â. (2005) 'Flexibilização de direitos, flexibilização do emprego: um estudo comparado da indústria de eletrodomésticos de linha branca', XII Congresso Brasileiro de Sociologia, Belo Horizonte, May 31-June 3

Arbix, G. \& A. Rodriguez-Posi (1999) 'Estratégias do Desperdício: A guerra fiscal e as incertezas do desenvolvimento', Novos Estudos Cebrap, no. 54. São Paulo: CEBRAP

Bresciani, L.P. (1997) 'Os desejos e o limite: reestruturação industrial e ação sindical no complexo automotivo brasileiro' in M. Leite (ed) O Trabalho em Movimento, Campinas: Papirus.

Bruschini, C (1997) O trabalho das mulheres no Brasil: continuidade e mudança no período 85-95. Relatório de Pesquisa: OIT

Bruschini, C. \& M.R. Lombardi (2003) 'Mulheres e homens no mercado de trabalho brasileiro. Um retrato dos anos 1990' in M. Maruani \& H. Hirata (eds) As novas fronteiras da desigualdade. Homens e mulheres no mercado de trabalho, São Paulo: Editora Senac.

Carvalho, E. G. (2005) 'Globalização e estratégias competitivas na indústria automobilística: Uma abordagm a partir das principais montadoras instaladas no Brasil'. Revista Gestão e Produção, vol 12, no1, Jan-April

Carleial, L (1997) 'Reestruturação Industrial, Relação entre Firmas e Mercado de Trabalho: as evidências na indústria eletro-eletrônica na região metropolitana de Curitiba' in L. Carleial \& R. Valle (eds.) Reestruturação Produtiva e Mercado de Trabalho no Brasil', São Paulo: HUCITEC/ ABET

Carleial, L, M. Gomes Filha \& L. Neves (2002) 'A gestão da força-de-trabalho na indústria automotiva: uma primeira aproximação a partir dos casos da Renault e da Audi-VW' in M. R.Nabuco, M. de Almeida Neves \& A. Moreira de Carvalho Neto (eds.) Indústria Automotiva: a nova geografia do setor produtivo, Rio de Janeiro: DP\&A.

Castro, N. (1994) 'Trabalho e reorganização industrial num contexto de crise e reestruturação produtiva', São Paulo em Perspectiva, São Paulo: Fundação Seade, vol 8, nº 1 
Consoni, F. (2004) Relatório final sobre o setor automobilístico, apresentado à FINEP

(Financiadora de Estudos e Pesquisa), Rio de Janeiro: FINEP

De Negri, J., F. De Negri \& D. Coelho (eds) (2006) Tecnologia, Exportação e Emprego, Brasília:

IPEA

DIEESE (2005) Workers Year-book, São Paulo: Departamento Intersindical de Estatística e

Estudos Socioeconômicos

Gitahy, L. \& F. Rabelo (1991) 'Educação e Desenvolvimento Tecnológico: o caso da indústria de autopeças', Textos para Discussão no 11. Campinas: DPCT/UNICAMP

Goldstein, A. (2002) 'Embraer: De campeón nacional a jugador global', Revista de la CEPAL, No

77, Agosto, Santiago de Chile: CEPAL

Hirata, H. (1983) 'Receitas Japonesas, Realidade Brasileira', Novos Estudos Cebrap, no 2, São

Paulo: CEBRAP.

Hirata et al (1992) 'Alternativas sueca, italiana e japonesa ao paradigma fordista: elementos para a discussão do caso brasileiro', Gestão da Qualidade, Tecnologia e Participação. Cadernos CODEPLAN 1, Brasília: DF

Hirata, H. (1998a) 'Restructuration Industrielle et Division Sexuelle du Travail: une perspective comparative' Revue Tiers Monde, no. 154, Paris: Presses Uiversitaires de France

Hirata, H (1998b) - 'Reorganização da Produção e Transformações do Trabalho: uma

perspectiva norte-sul' in Antonio Moreira de Carvalho Neto and Ricardo Augusto Alves de

Carvalho - Sindicalismo e Negociação Coletiva nos anos 1990. Belo Horizonte, Instituto de

Relações do Trabalho, PUC/MINAS.

Humphrey, J. (1991) 'Japanese methods and the changing position of direct production workers: evidence from Latin America'. Brighton: IDS, University of Sussex, Falmer, mimeo.

Leite, M. P. (1994) O Futuro do Trabalho. Novas Tecnologias e Subjetividade Operária. São Paulo: Scritta.

Leite, M. P. (2000) 'Trabalho e Qualificação na Indústria Automobilística: novas tendências, velhos problemas' in Alice Abreu (ed.) Produção Flexível e Novas Institucionalidades na América Latina, Rio de Janeiro: Editora da UFRJ

Leite, M. P. (2003) Trabalho e Sociedade em Transformação. Mudanças Produtivas e Atores Sociais, São Paulo: Fundação Perseu Abramo

Leite, M. P. \& R. Silva (1991) 'Tecnologia Moderna e Relações de Trabalho Conservadoras: a contradição brasileira?' in M. P. Leite \& R. A. da Silva (eds) Modernização Tecnológica, Relações de Trabalho e Práticas de Resistência, São Paulo: Iglu/ILDES/ labour.

Leite, M. P. \& C. Rizek (1998) 'Cadeias, Complexos e Qualificações' in M. P. Leite \& M.de Almeida Neves (eds). Trabalho, Qualificação e Formação Profissional. Série II Congresso Latino Americano de Sociologia do Trabalho. São Paulo/Rio de Janeiro: ALAST

Martins, H. \& J. R. Ramalho (1994) (eds.) - Terceirização, Diversidade e Negociação no Mundo do Trabalho. São Paulo: HUCITEC/CEDI-NETS

Motim, B., O.Firkowski, \& S.Araújo (2002) 'Industria Automobilística no Paraná: implicações sobre o emprego e as relações de trabalho' in M. R. Nabuco, M. de Almeida Neves \& A. Moreira de Carvalho Neto (eds.) Indústria Automotiva: a nova geografia do setor produtivo, Rio de Janeiro: DP\&A

Nabuco, M. R. \& M. Mendonça (2002) 'Estratégias de localização do setor automobilístico no Brasil: o caso da Mercedes-Benz' in Maria Regina Nabuco, Magda de Almeida Neves e Antonio Moreira de Carvalho Neto (eds) Indústria Automotiva: a nova geografia do setor produtivo, Rio de Janeiro: DP\&A.

Nabuco, M. R, M. A. Neves, \& A.N. Carvalho Neto (2002) (eds.) Indústria Automotiva: a nova geografia do setor produtivo, Rio de Janeiro: DP\&A.

Negri, J., M. Salerno \& A. Castro (2005) 'Inovações, Padrões Tecnológicos e Desempenho das Firmas Industriais Brasileiras' in J. A. de Negri \& M. S. Salerno (eds.) Inovações, Padrões Tecnológicos e Desempenho das Firmas Industriais Brasileiras, Brasília: IPEA.

Neto, R.\& S. Kassicieh (2004) 'Shifting the Technology Paradigm: Moving Towards

Commercialization', Latin American Business Review, vol 4, no 3, 23 February 2004:91-109 
Pimenta, S \& M.Correa (2002) 'Inovações Organizacionais e Mobilização da Subjetividade: o sistema de gestão da Mercedes-Benz’ in M. R. Nabuco, M. de Almeida Neves \& A. M. de Carvalho Neto (eds) Indústria Automotiva: a nova geografia do setor produtivo, Rio de Janeiro: DP\&A Pochmann, M, C. Salas \& M. P. Leite (2007) 'Mercado de trabajo. Qué hay de nuevo en Brasil?' Revista Trabajo, México, UAM-OIT, vol 3, No 1

Posthuma, A. and Lombardi, M. R. (1997) 'Mercado de trabalho e exclusão social da força de trabalho feminina', Revista São Paulo em Perspectiva, vol 11, no 1, January-March, São Paulo: Fundação Seade Ramalho, J. R. \& M.A. Santana (2002) 'A indústria automotiva no Rio de Janeiro. Relações de trabalho em um contexto de desenvolvimento', in M. R. Nabuco,

M, de Almeida Neves \& A.M. de Carvalho Neto (eds.) Indústria Automotiva: a nova geografia do setor produtivo,. Rio de Janeiro: DP\&A.

Ruas, R. \& E. Antunes (1997) 'Gestão do Trabalho, Qualidade Total e Comprometimento no Cenário da Reestruturação', São Paulo em Perspectiva, vol 11, no 1, São Paulo: Fundação Seade Salerno, M. S. (1985) 'Produção, Trabalho e Participação: CCQ e Kanban numa nova imigração japonesa' in M. T. Fleury \& R. M. Fischer (eds) Processos e Relações de Trabalho no Brasil. São Paulo: Atlas

Salerno, M. S. (1998) 'Restructuration de la production et travail dans les entreprises installés au Brésil' Revue Tiers Monde, vol XXXIX, no154, Les Transformations du Travail (Amerique Latine, Asie) Paris: Presses Universitaires de France

Segnini, L. (1998) 'Relações de Gênero no Trabalho Bancário no Brasil' in N. Castro \& C. Dedecca (eds) A Ocupação na América Latina: Tempos mais Duros. Série II Congresso Latino Americano de Sociologia do Trabalho, São Paulo \& Rio de Janeiro: ALAST

Zawislak, P. \& A. Melo (2002) 'A indústria automotiva no Rio Grande do Sul: impactos recentes e alternativas de desenvolvimento' in M. R. Nabuco, M. de Almeida Neves \& A. M. de Carvalho Neto (eds) Indústria Automotiva: a nova geografia do setor produtivo. Rio de Janeiro: DP\&A

\section{ACKNOWLEDGEMENTS}

I would like to thank Carlos Salas for his work on translating and editing this paper. An earlier version of this paper was published in Huws U., S. Dahlmann \& A. Dhudwar (eds)(2006) The transformation of work in a global knowledge economy: towards a conceptual framework: WORKS conference proceedings, Leuven: Catholic University of Leuven. 